Ann. Biol. anim. Bioch. Biophys., 1979, 19 (4 A), 1099-1108.

\title{
Plasma steroids, prolactin and placental lactogen in intact or hypophysectomized pregnant ewes with an hypophysectomized foetus. Effect of foetal perfusion of dexamethasone
}

by M. J. BOSC, Ph. DURAND, A. LOCATELLI, Agnès NICOLLE, J. P. RAVAULT,* M. TERQUI

Station de Physiologie de la Reproduction, I.N.R.A., Nouzilly, 37380 Monnaie.

* Laboratoire de Physiologie comparée, Faculté des Sciences, 37200 Tours.

Summary. Progesterone, total oestrogens (mainly conjugated and unconjugated oestrone), prolactin and placental lactogen have been determined during late pregnancy in the peripheral plasma of intact or hypophysectomized ewes after destruction of the foetal pituitary. During the prolongation of gestation due to the removal of the foetal hypophysis, progesterone and placental lactogen remained at a high level, while total oestrogens and prolactin maintained a low concentration. When the foetus was perfused for 2 days with dexamethasone, the induced lambing was preceded by a fall in progesterone concentrations followed by a decrease in placental lactogen ; at the same time, an abrupt increase in oestrogens and prolactin was observed.

In the ewe, the foetal pituitary adrenal axis controls the time of parturition by the secretion of cortisol (Liggins ef al., 1967 ; Liggins, 1968). This effect can be mimicked by infusion into the folus of dexamethasone or cortisol (Liggins, 1968). Furthermore, at the end of pregnancy a dexamethasone administration to the mother induces lambing (Bosc, 1970). This latter procedure momentarily inhibits cortisol secretion by the fœtal adrenals and then stimulates it (Bosc and Fèvre, 1974). If the fœtus has been hypophysectomized however, administration of cortisol to the mother does not induce delivery (Bosc, 1972) while perfusion into the fœtus results in the birth of the lamb (Kendall et al., 1977). In order to compare the two groups of experiments we report the variations of concentrations of progesterone and œstrogens in maternal plasma obtained with a dexamethasone perfusion into hypophysectomized fatus having an intact or a hypophysectomized mother. In this study, the concentrations of prolactin and of placental lactogenic hormone were also determined. 


\section{Material and Methods.}

Animals : Seven multiparous ewes of the lle-de-France breed were used in this study. They were mated during œstrus season with rams of the same breed (day of mating $=$ day 0 of pregnancy). At about day 120 of pregnancy, the fotal pituitary gland was destroyed under general anaesthesia as previously described (Bosc, 1972 ; Bosc and Fèvre, 1975). At the same time, the maternal hypophysis was removed by the parapharyngeal route in 2 animals (Denamur and Martinet, 1961) ; these 2 ewes were then placed in a hot room (about $25^{\circ} \mathrm{C}$ ).

At about the beginning of the lambing period of the control sheep (between days 143 and 151 under our conditions) a catheter (polyethylène-Biotrol) was inserted into a fœtal cotyledonary vein (fable 1). Just after surgery, the animals were put into a cage $(150 \times 60 \mathrm{~cm})$ and the free end of the catheter was then connected to a syringe on a perfusion pump. The perfusion was started just after recovery. A heparinized solution of sterile physiological saline was then perfused $(0.4 \mathrm{ml} / \mathrm{h})$ over 2 days. $\ln 5$ cases, dexamethasone phosphate (Intervet) was added $(0.10$ or $0.09 \mathrm{mg} / \mathrm{ml}$ ) ; the total dose perfused was calculated at the end of the treatment (see table 1).

Assessment of hypophysectomy: Hypophysectomy was assessed after delivery and/or at slaughter by examination of the brain. The plasma level of prolactin was determined in the live lambs, a level around the assay sensitivity indicating the absence of pituitary tissue.

Sampling : Maternal blood was drawn by jugular venepuncture into heparinized tubes $(5 \mathrm{ml})$, starting before surgery and ending, after perfusion, at lambing or at slaughter. Sampling frequencies are shown on the figures. The blood was immediately centrifuged and the plasma divided into aliquots and stored at $-15^{\circ} \mathrm{C}$ until analysis.

Hormone assays : The steroids were assayed by radioimmunoassay. Progesterone was determined according to Palmer and Jousset (1975) with the following steps : plasma extraction $(0,5 \mathrm{ml})$ with hexane $(5 \mathrm{ml})$; after evaporation, addition of a phosphate-buffered solution containing tritiated progesterone and a specific antiserum (Yenikoye, 1977) then separation of the free and bound fractions by double antibody precipitation and counting. Under these conditions, the sensitivity of the assay was $0.3 \mathrm{ng} / \mathrm{ml}$. The conjugated and unconjugated cestrogens were determined according to Palmer and Terqui (1977) and Terqui (1978). The plasma $(0.5 \mathrm{ml})$ was incubated overnight at $40^{\circ} \mathrm{C}$ with a solution of Helix Pomatia hepatopancreatic juice secretion IBF-France) ; in these conditions, the recovery after hydrolysis is 80-90 p. 100 (Terqui, 1978). The hydrolized solution was diluted and extracted with cyclohexane-ethylacetate ( $1 / 1$ by vol). An antiserum raised against œstrone-17-hydrazone BSA was used before the separation of the free and bound fractions and counting. This antiserum cross-reacted with œstrone (100 p. 100) but also with œstradiol-17 $\beta$ (39 p. 100) and œstradiol-17 $\alpha$ (26 p. 100); as cestrone (conjugated and unconjugated) represents most of the cestrogens (at least 80-90 p. 100) during late pregnancy in sheep (Terqui, 1978), the results were expressed in œstrone equivalents. 
Ovine prolactin was examined by radioimmunoassay (Kann, 1971) ; sensitivity was $0.3 \mathrm{ng} / \mathrm{ml}$ (standard NIH PS6). Ovine placental lactogen (OPL) was determined by a radioreceptor assay (Djiane and Kann, 1975) using membranes prepared from rabbit mammary glands which were previously desaturated by removing the endogenous hormone in vivo (Durand and Djiane, 1977). This procedure is specific for hormones having a lactogenic activity and therefore the level of OPL was obtained by subtracting the prolactin value from the total lactogenic activity of the plasma; the sensitivity of the assay under these conditions was $20 \mathrm{ng} / \mathrm{ml}$ of ovine prolactin equivalent.

\section{Results.}

The destruction of fœtal pituitaries was complete in all cases as was the removal of those of the 2 operated mothers (ewes 6 and 7). This was confirmed by the plasma level of prolactin $(<1 \mathrm{ng} / \mathrm{ml}$ ) in 4 fœtuses (fœtuses of ewes $1,2,3,4)$ and in the 2 hypophysectomized ewes.

Details of the timing of the experiment are presented on table 1. The 2 animals (ewes 1 and 2) with fotuses perfused with physiological saline, did not lamb they carried the fotuses alive until the time of slaughter at day 152 of pregnancy. In contrast,

TABLE 1

Perfusion of physiological saline or dexamethasone into an hypophysectomized sheep foetus

\begin{tabular}{|c|c|c|c|c|c|c|}
\hline \multirow[b]{2}{*}{$\begin{array}{c}\text { Ewe } \\
\text { nos }^{\text {os }}\end{array}$} & \multicolumn{2}{|c|}{ Hypophysectomy } & \multicolumn{2}{|c|}{ Perfusion } & \multirow{2}{*}{$\begin{array}{l}\text { Dexamethasone } \\
\text { total dose } \\
(\mathrm{mg})\end{array}$} & \multirow[b]{2}{*}{ Results } \\
\hline & Site & $\begin{array}{l}\text { Gestational } \\
\text { age at } \\
\text { surgery }\end{array}$ & $\begin{array}{l}\text { Start } \\
\text { (days) }\end{array}$ & $\begin{array}{l}\text { Duration } \\
\text { (hours) }\end{array}$ & & \\
\hline 1 & Fœtus & 120 & 146 & 47 & 0 & $\begin{array}{l}\text { Prolongation to day } 152 \text {. Fotus ali- } \\
\text { ve }(6.4 \mathrm{~kg})\end{array}$ \\
\hline 2 & Fœtus & 122 & 144 & 47 & 0 & $\begin{array}{l}\text { Prolongation to day } 152 \text {. Fotus ali- } \\
\text { ve }(5.2 \mathrm{~kg})\end{array}$ \\
\hline 3 & Fœtus & 123 & 143 & 47 & 2.1 & $\begin{array}{l}\text { Parturition } 52 \mathrm{hrs} \text { after the start of } \\
\text { infusion, lamb alive }(4.2 \mathrm{~kg})\end{array}$ \\
\hline 4 & Fœtus & 118 & 145 & 47 & 2,1 & $\begin{array}{l}\text { Parturition } 52 \mathrm{hrs} \text { after the start of } \\
\text { infusion, lamb alive }(4.2 \mathrm{~kg})\end{array}$ \\
\hline 5 & Fœtus & 117 & 143 & 46.40 & 1.95 & $\begin{array}{l}\text { Parturition } 61 \text { hrs after the start of } \\
\text { infusion, lamb probably alive at } \\
\text { birth }\end{array}$ \\
\hline 6 & $\begin{array}{l}\text { Fotus } \\
\text { Mother }\end{array}$ & $\begin{array}{l}117 \\
117\end{array}$ & 142 & ${ }^{48}-$ & $\begin{array}{l}1.9 \\
0\end{array}$ & $\begin{array}{l}\text { Parturition } 60 \mathrm{hrs} \text { after the start of } \\
\text { infusion *, lamb probably alive at } \\
\text { birth }(3.2 \mathrm{~kg})\end{array}$ \\
\hline 7 & $\begin{array}{l}\text { Fœtus } \\
\text { Mother }\end{array}$ & $\begin{array}{l}119 \\
119\end{array}$ & $\frac{145}{-}$ & $\stackrel{29.30}{-}$ & $\begin{array}{l}1.5 \\
0\end{array}$ & $\begin{array}{l}\text { Death of the ewe } 29.30 \mathrm{hrs} \text { after the } \\
\text { start of infusion, lamb probably } \\
\text { alive at that time }(4.8 \mathrm{~kg})\end{array}$ \\
\hline
\end{tabular}

* Estimated time of parturition. 
perfusion of about $2 \mathrm{mg}$ of dexamethasone was followed by parturition after a mean time of $55 \mathrm{hrs}$ (range 52-61 hrs) after the start of treatment (ewes 3, 4 and 5). Two lambs were alive at birth (ewes 3,4 ); the another (ewe 5), found dead, was probably alive before delivery. This was supported by its general appearance and the separate expulsion of the placenta ; it did not survive probably because it was unable to breathe due to the destruction of a part of the brain as a consequence of surgery.
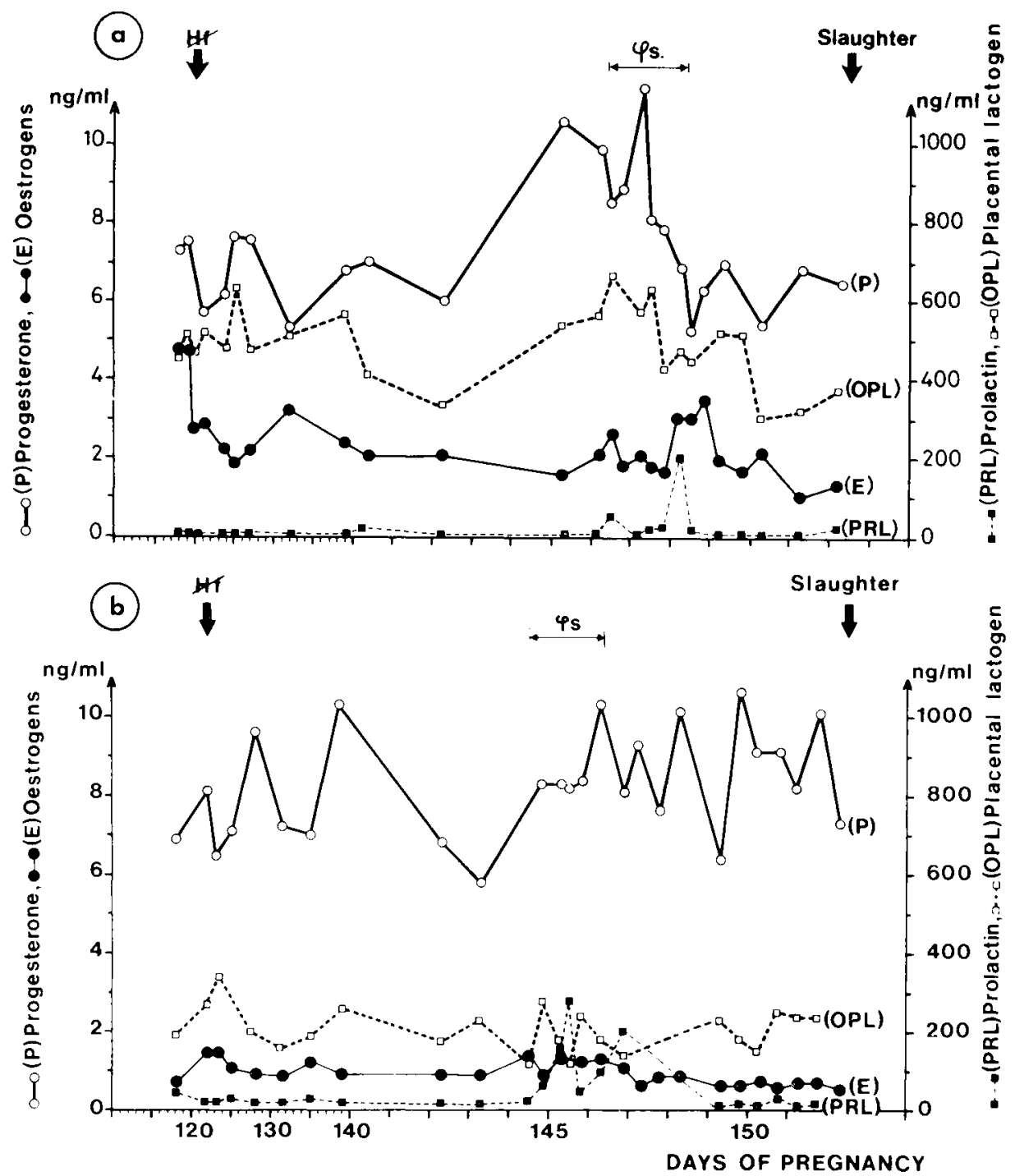

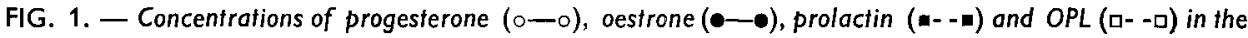
maternal plasma of 2 ewes (ewes $n^{0 s} 1$ and 2 ) after hypophysectomy of the foetus $(\mathrm{Hf})$ and during intrafoetal perfusion of physiological saline ( $\varphi s)$. $a$ : ewe $n^{0} 1,1$ foetus; $b$ : ewe $n^{0} 2,1$ foetus. 
Lambing occurred $60 \mathrm{hrs}$ after the start of perfusion of dexamethasone for 1 of the 2 hypophysectomized ewes (ewe 6) ; the other (ewe 7) was found dead $1 \mathrm{~h} 30$ after examination; its lamb was not engaged in the cervival canal and should have been alive at the death of its mother.

The hormonal profiles of 6 ewes are presented in figures $1,2,3$. With perfusion of physiological saline (fig. 1) the plasma progesterone concentrations remained above $5 \mathrm{ng} / \mathrm{ml}$; an increase was seen at the time of the second surgical intervention. The level of OPL followed a variation similar to progesterone. The œstrogens (unconjugated and conjugated cestrone essentially) showed no marked changes except a short increase during the perfusion period in 1 animal (ewe 1).

By comparison, after the beginning of dexamethasone perfusion, the progesterone fells rapidly to a very low level at the time of birth ; this decrease was also preceded by a transient increase which corresponded to the insertion of the perfusion catheter. The OPL concentrations followed a pattern similar to that for progesterone but their decrease occurred later. The levels of œstrone showed a dramatic increase above $10 \mathrm{ng} / \mathrm{ml}$ after the start of the corticosteroid treatment and declined after lambing (fig. 2 and 3). After the removal of the maternal pituitary there was no detectable prolactin (fig. 3 ) whereas in the intact mother there was a peak of this hormone at the time of expulsion of the lamb (fig. 2).

Table Il gives the variations of the mean concentrations of progesterone total œstrogens and OPL from the time of removal of the fotal or maternal pituitaries to the time of perfusion. As the number of animals was low, especially in the case of maternal

TABLE 2

Plasma concentrations of progesterone, œstrone and OPL between surgery and the beginning of corticosteroid perfusion in intoct or hypophysectomized mothers carrying an hypophysectomized fœtus

\begin{tabular}{|c|c|c|c|c|c|}
\hline & \multirow{2}{*}{ Status of the mother } & \multicolumn{4}{|c|}{ Days of pregnancy } \\
\hline & & $125-129$ & $130-134$ & $135-139$ & $140-143$ \\
\hline $\begin{array}{l}\text { Progesterone } \\
\qquad(\mathrm{ng} / \mathrm{ml})\end{array}$ & $\begin{array}{l}\text { Intact } \ldots \ldots \ldots \ldots \ldots \ldots \\
\mathrm{H}^{-} \ldots \ldots \ldots \ldots \ldots \ldots\end{array}$ & $\begin{array}{c}7,34 \pm 1,22 \\
(10) \\
6,60 \pm 1,47 \\
\frac{(3)}{(3)}\end{array}$ & $\begin{array}{c}8,08 \pm 1,93 \\
\frac{(6)}{(6)} \\
7,30 \frac{ \pm}{(3)} 1,67\end{array}$ & $\begin{array}{l}7,88 \pm 1,41 \\
\frac{(8)}{(8)} \\
6,87 \frac{ \pm}{(3)} 1,71\end{array}$ & $\begin{array}{c}6,6 \pm 0,82 \\
(10) \\
7,38 \underset{ }{\frac{(4)}{(4)}}\end{array}$ \\
\hline $\begin{array}{l}\text { Oestrone } \\
(\mathrm{ng} / \mathrm{ml})\end{array}$ & $\begin{array}{l}\text { Intact } \ldots \ldots \ldots \ldots \ldots \ldots \\
\mathrm{H}-\ldots \ldots \ldots \ldots \ldots \ldots\end{array}$ & $\begin{array}{c}1,34 \pm 0,46 \\
\quad(9) \\
0,57 \stackrel{ \pm}{ \pm} 0,12 \\
(3)\end{array}$ & $\begin{array}{c}1,55 \pm 1,13 \\
(4) \\
0,70 \frac{ \pm}{(2)} 0,14\end{array}$ & $\begin{array}{l}1,30 \underset{+}{(7)} 0,59 \\
0,77 \frac{ \pm}{\frac{ \pm}{(3)}} 0,29\end{array}$ & $\begin{array}{c}1,16 \pm 0,01 \\
(11) \\
1,20 \pm 0,26 \\
(4)\end{array}$ \\
\hline$\underset{(\mathrm{ng} / \mathrm{ml})}{\mathrm{OPL}}$ & $\begin{array}{l}\text { Intact } \ldots \ldots \ldots \ldots \ldots \ldots \\
\mathrm{H}-\ldots \ldots \ldots \ldots \ldots \ldots\end{array}$ & $\begin{array}{c}318 \pm 181 \\
(10) \\
411 \frac{ \pm}{(3)}\end{array}$ & $\begin{array}{c}368 \underset{(6)}{ \pm} 217 \\
494 \underset{(3)}{ \pm} 102\end{array}$ & $\begin{array}{c}303 \frac{ \pm}{(8)} \\
616 \underset{(3)}{ \pm} 166\end{array}$ & $\begin{array}{c}286 \pm 79 \\
(10) \\
513 \pm 193 \\
(4)\end{array}$ \\
\hline
\end{tabular}

$\mathbf{m} \pm \mathbf{s d} ;$ ( ) Number of plasmas of 5 intact and 2 hypophysectomized ewes. 


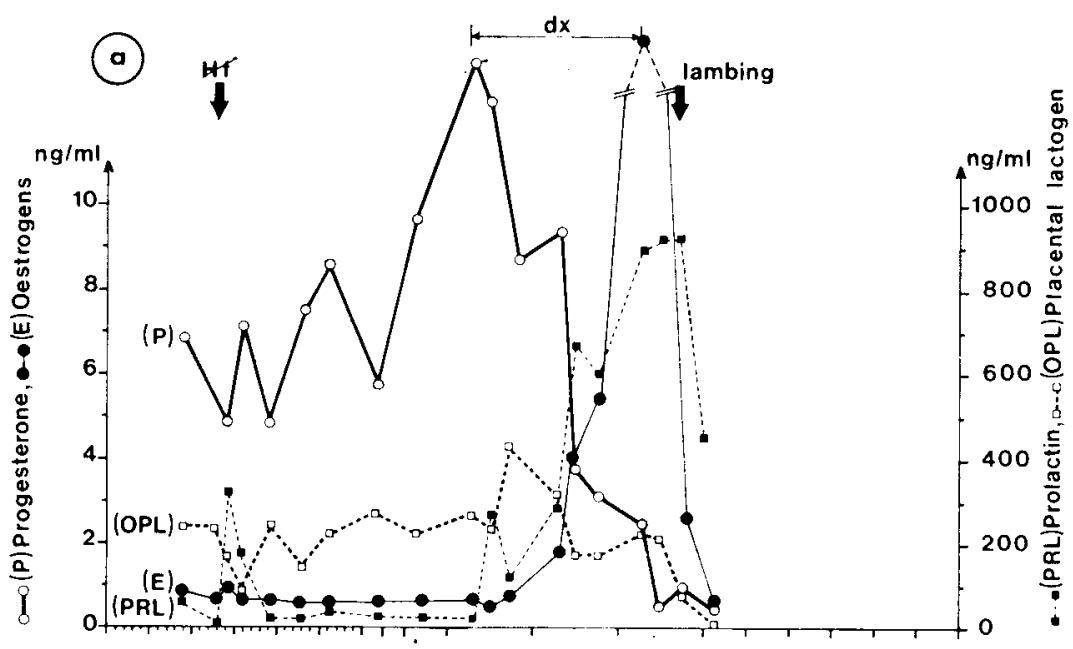

(b)

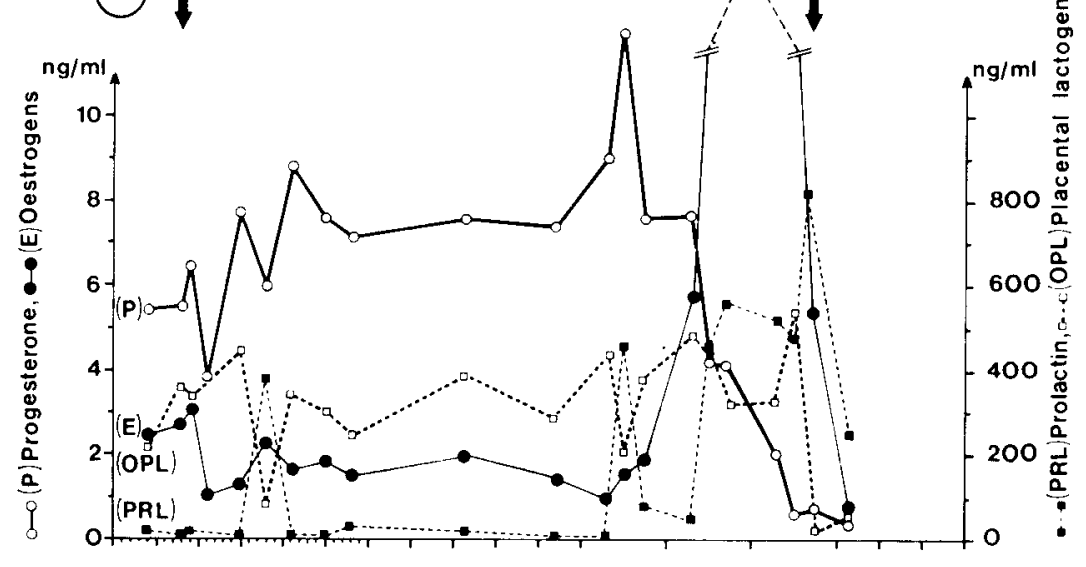

(c)

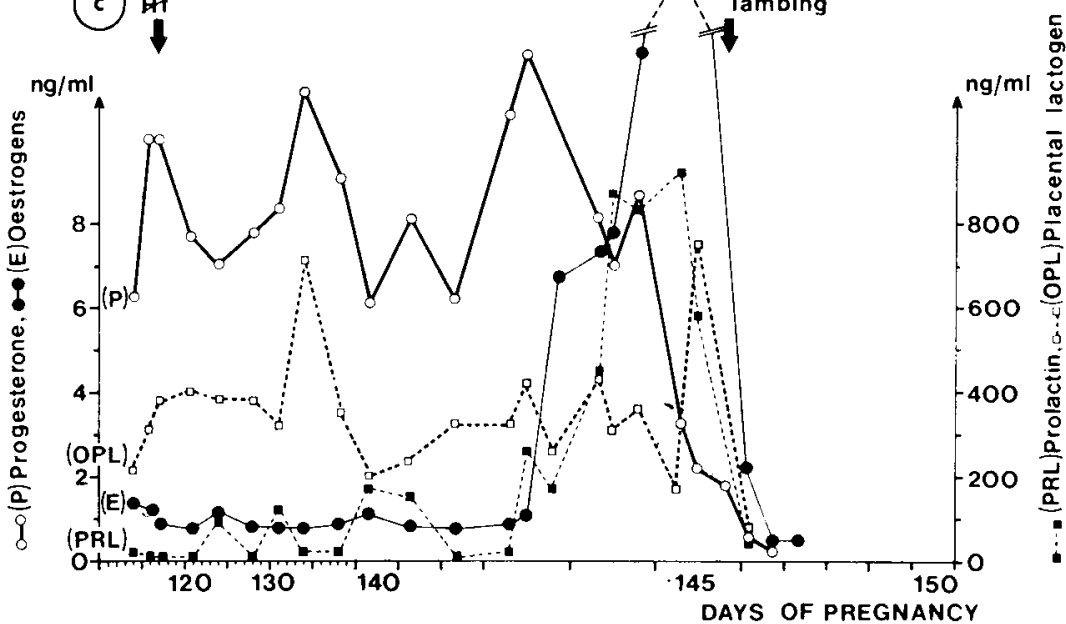


hypophysectomy, these values should be considered as indicative. However it seemed that after removal of the pituitary of the mother, the levels of total œstrogens were lower and those of OPL higher than those of the intact ewes.

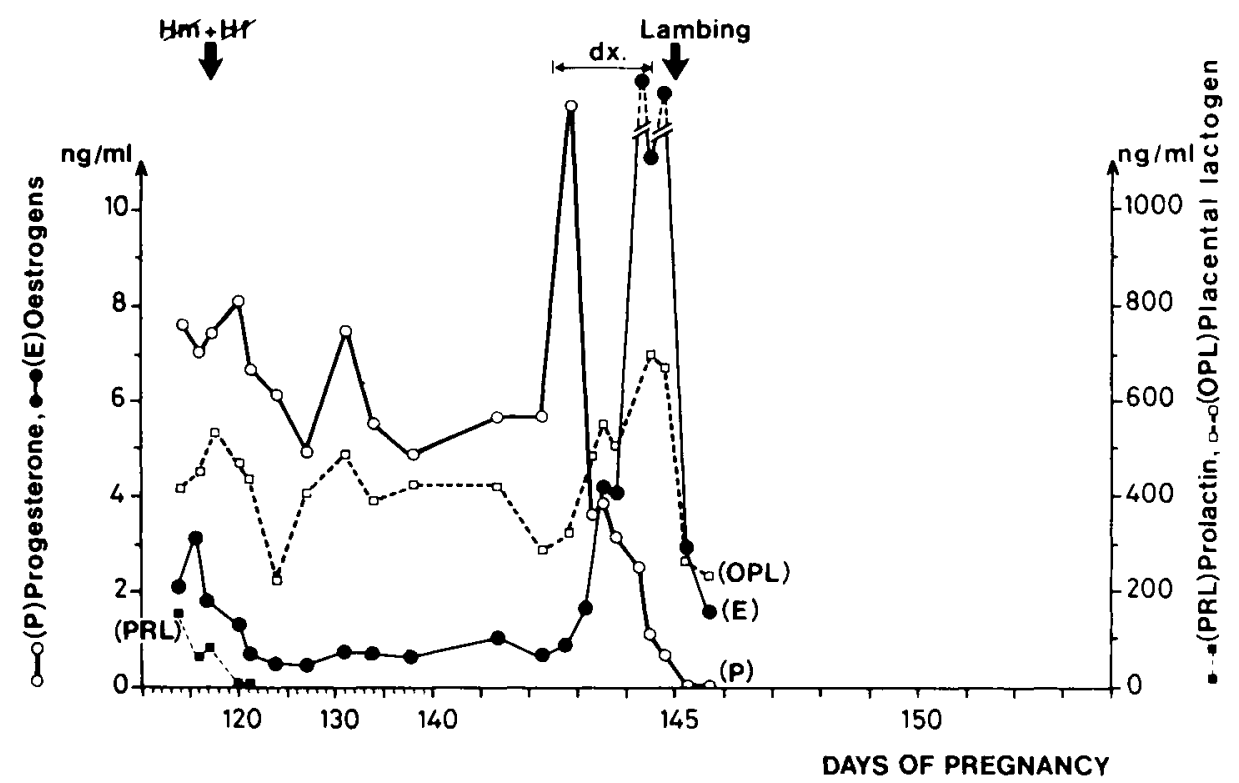

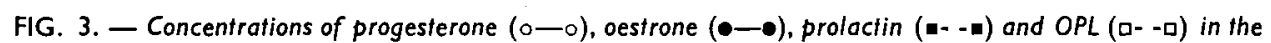
maternal plasma of an hypophysectomized ewe $(\mathrm{Hm})$ (ewe $\left.n^{\circ} 6\right)$ after hypophysectomy of the foetus $(\mathrm{Hf})$ and during intrafoetal perfusion of dexamethasone $(\mathrm{dx})$.

\section{Discussion.}

Hypophysectomy of the fœtus leads to prolongation of gestation in sheep (Liggins ef al., 1967). The present study confirms this by the maternal plasma concentrations in progesterone (Bosc and Fèvre, 1975) and in cestrone or total œstrogens (Kendall ef al., 1977) which remained at the levels observed during the pre-partum time. The results also show that a dexamethasone perfusion over 2 days into a hypophysectomized fotus resulted in delivery of the lamb which was preceded by a fall in plasma progesterone and a large increase in cestrogens; these hormonal changes were similar to that occurring before natural lambing which has often been described (Bedford ef al., 1972 ; Thorburn ef al., 1972 ; Liggins et al., 1973).

These data agree with earlier reports (Flint ef al., 1975 ; Kendall et al., 1977) and with infusion experiments using adrenocorticotropin (Kendall, ef al., 1977 ; Jones

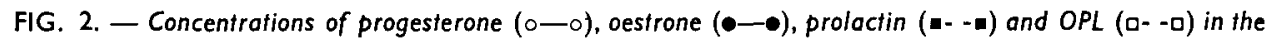
maternal plasma of 3 ewes (ewes nos 3,4 and 5) affer hypophysectomy of the foefus (Hf) and during intrafoetal perfusion of dexamethasone $(d x)$. $a$ : ewe $n^{\circ} 3,1$ foetus ; $b$ : ewe $n^{\circ} 4,1$ foetus ; $c$ : ewe $\mathrm{n}^{\circ} 5,1$ foetus. 
ef al., 1978). This effect of intrafotal perfusion of dexamethasone appears to contradict the fact that one administration of this compound to the mother does not induce the expulsion of a hypophysectomized fœtus (Bosc, 1972). This discrepancy between the two groups of results has been attributed to the alteration of placental permeability following destruction of the fotal pituitary (Kendall ef al., 1977). In fact after such surgery, the placenta is affected, as shown by ultrastructural changes (Barnes et al., 1976) such as is a thickening of the basement membrane of the chorionic epithelium. This objection however does not really resolve the question becuuse the destruction of the foetal pituitary does not suppress the passage of dexamethasone into the foetal compartment (Bosc and Terqui, to be published). After one administration of dexamethasone to the mother, this steroid passes through the placenta (Bayard et al., 1972) and causes a transient fall in the fœetal cortisol level of intact sheep which lasts less than $24 \mathrm{hrs}$ (Bosc and Fèvre, 1974) and is followed by a rebound stimulation of its secretion. Such an administration can be interpreted as a short perfusion. After hypophysectomy of the fotus, it can be postulated that there is no rebound elevation of foetal cortisol after administration of dexamethasone to the mother. By comparison, under the conditions of the present study, over $48 \mathrm{hrs}$ of perfusion caused birth of the lamb. So the two groups of results indicate that a minimum time (between 24 and $48 \mathrm{hrs}$ ) is required for the fotal corticosteroids to activate the placental enzyme systems controlling uterine motility.

In this experiment, an elevation of progesterone concentrations was observed at the beginning of perfusion. This increase could be attributed to experimental conditions around the time of perfusion including one day of fasting, surgery for insertion of a catheter, and subsequent management of the animal during the treatment. Such an effect has already been observed in sheep (Donaldson et al., 1970 ; Goding and Bassett, 1973).

The surge of total œstrogens during the perfusion of dexamethasone after fœtal hypophysectomy contrasts with the lack of variation of the unconjugated $\propto$ stradiol-17 $\beta$ (Kendall ef al., 1977). This suggests an insufficiency of the $17 \beta$-hydroxysteroid deshydrogenase in the absence of a fotal pituitary factor. The results found after incomplete hypophysectomy of the fœlus support this possibility (Kendall et al., 1977). This hypophyseal factor is perhaps prolactin which is not found after removal of the pituitary and is known to increase the $17 \beta$-hydroxysteroid deshydrogenase activity in the testis (Musto et ol., 1972). In this study, hypophysectomy of the mother seemed to affect concentrations in œstrogens since they were lower than in normal ewes (table 2). In the ewe the main site of œstrogen production is the placenta (Davies ef al., 1970 ; Challis ef al., 1974) and the fotal (Flint ef al., 1975) and maternal (Thompson and Wagner, 1974) adrenals can afford to contribute. The latter contribution has perhaps been diminished in the absence of the pituitary under our conditions. Another reason may be the general metabolic status of such an operated animal; this is confirmed by the lower concentrations of progesterone also observed in this case (table 2). In this experiment, the temporal patterns of progesterone and OPL in the plasma show a similarity during prolongation of gestation as well as during the induced lambing. This similarity has been observed in normal pregnant ewes (Kelly ef al., 1974) and in our study the concentrations in OPL appear to be in the same range as in normal gestation (Djiane and Kann, 1975). The factors which regulate the production of 
placental lactogen are not known. These results suggest that the fotal pitutiary is not involved in its secretion. However the OPL plasma levels seem to increase after the removal of the maternal hypophysis (table 2). In the same way, the suppression of prolactin release by giving bromoergocryptine to intact pregnant ewes enhances OPL concentrations in the placenta (Martal and Lacroix, 1978). These facts may suggest some relationship between the production of the two lactogenic hormones.

Reçu en novembre 1978.

Accepté en mars 1979.

Résumé. Les variations des concentrations de la progestérone, des œestrogènes totaux, de la prolactine et de l'hormone placentaire lactogène ont été déterminées dans cette étude, après hypophysectomie du fotus pratiquée vers le $120^{\circ}$ jour de la gestation, la brebis étant normale ou elle-même hypophysectomisée. L'effet d'une perfusion du fœetus par la dexaméthasone a été aussi étudiée. L'hypophysectomie du fœtus chez la Brebis entraîne la prolongation de la gestation et, dans ces conditions, les concentrations de progestérone et d'œstrogènes, d'une part, de prolactine et d'hormone placentaire lactogène (OPL), d'autre part, ne sont pas affectées ; la progestérone et l'OPL restent à des niveaux élevés alors que les œstrogènes ou la prolactine, ont des taux faibles. Lorsque le fœius hypophysectomisé est perfusé pendant deux jours avec une solution contenant de la dexaméthasone (environ $2 \mathrm{mg}$ ), l'agnelage est provoqué ; il est précédé par la baisse du taux de la progestérone et, ensuite, par celle de l'OPL alors que les taux de l'œestrone, puis de la prolactine, subissent une augmentation brutale.

\section{References}

BARNES R. J., COMLINE R. S., SILVER M., STEVEN D. H., 1976. Ultrastructural changes in the placenta of the ewe after foetal hypophysectomy or adrenalectomy. J. Physiol. (London), 263, 173P-174P.

BAYARD F., LOUVET J. P., RUCKEBUSCH Y., BOULARD C. I., 1972. Transplacental passage of dexamethasone in sheep. J. Endocr., 54, 349-350.

BEDFORD C. A., CHALLIS J. R. G., HARRISON F. A., HEAP R. B., 1972. The role of oestrogens and progesterone in the onset of parturition in various species. J. Reprod. Fert., Suppl., 16, 1-23.

BOSC M. J., 1970. Etude de l'induction de la parturition chez la brebis par un corticosteroide de synthèse le fluoro méthyl prednisolone. C. R. Acad. Sci. Paris, Sér. D, 270, 3127-3130.

BOSC M. J., 1972. Conséquences sur la parturition de l'hypophysectomie de la mère ou du fœius chez la brebis traitée par la dexamethasone. C. R. Acad. Sci. Paris, Sér. D, 274, 93-96.

BOSC M. J., FĖVRE J., 1974. Etude du mode d'action de la dexamethasone utilisée pour induire l'agnelage chez la brebis. C. R. Acad. Sci. Paris, Sér. D, 278, 315-318.

BOSC M. J., FÈVRE J., 1975. Evolution de la progestéronémie chez la brebis en fin de gestation après destruction de l'hypophyse fortale. Effef d'une administration de dexaméthasone. C. R. Acad. Sci. Paris, Sér. D, 281, 559-562.

CHALLIS J. R. G., HARRISON F. A., HEAP R. B., 1974. The extraction of oestrogens; and the rate of secretion of oestrone and oestradiol-17 $\beta$ by the uterus in the pregnant sheep. J. Endocr., 61, 277-284.

DAVIES J. J., RYAN K. J., PETRO Z., 1970. Estrogen synthesis by adrenal-placental tissues of the sheep and the iris monkey in vitro. Endocrinology, 86, 1457-1459.

DENAMUR R., MARTINET J., 1961. Effet de l'hypophysectomie et de la section de la tige pituitaire sur la gestation de la brebis. Ann. Endocr. Paris, 22, 755-759.

DJIANE J., KANN G., 1975. Mise en évidence de l'activité lactogène et mesure dans le sérum de l'activité prolactinique du placenta chez la brebis au cours de la gestation. C. R. Acad. Sci. Paris, Sér. D, 280, 2785-2788. 
DONALDSON L. E., BASSETT J. M., THORBURN G. D., 1970. Peripheral plasma progesterone concentrations of cows during puberty oestrous cycle pregnancy and lactation and the effects of undernutrition or exogenous oxytocin on progesterone concentration. J. Endocr., 48, 599614.

DURAND P., DJIANE J., 1977. Lactogenic activity in the serum of rabbits during pregnancy and early lactation. J. Endocr., 75, 33-42.

FLINT A. P. F., ANDERSON A. B. M., STEELE P. A., TURNBULL A. C., 1975. Effect of foetal adrenalectomy on maternal oestrogen levels at dexamethasone induced parturition in sheep. J. Endocr., 67, 25P.

GODING J. R., BASSETT J. M., 1973. In a discussion of Symp. The endocrinology of pregnancy and parturition. Experimentol studies in the sheep, Cardiff, 1971, ed. by C. G. PIERREPOINT, Tenovus Library series.

JONES C. T., KENDALL J. Z., RITCHIE J. W., ROBINSON J. S., THORBURN G. D., 1978. Adrenocorticotrophin and corticosteroid changes during dexamethasone infusion to intact and synacthen infusion to hypophysectomized foetuses. Acta endocrinol., 87, 203-211.

KANN G., 1971. Dosage radioimmunologique de la prolactine plasmatique chez les Ovins. C. $R$. Acad. Sci. Paris, Sér. D, 272, 2934-2937.

KELLY P. A., ROBERTSON H. A., FRIESEN H. G., 1974. Temporal pattern of placental lactogen and progesterone secretion in sheep. Nature, 248, 435-437.

KENDALL J. Z., CHALLIS J. R. G., HART I. C., JONES C. T., MITCHELL M. D., RITCHIE J. W. K., ROBINSON J. S., THORBURN G. D., 1977. Steroid and prostaglandin concentrations in the plasma of pregnant ewes during infusion of adrenocorticotrophin or dexamethasone to intact or hypophysectomized foetuses. J. Endocr., 75, 59-71.

LIGGINS G. C., KENNEDY P. C., HOLM L. W., 1967. Failure of initiation of parturition after electrocoagulation of the pituitary of the foetal lamb. Am. J. Obstet. Gynec., 98, 1080-1086.

LIGGINS G. C., 1968. Premature parturition after infusion of corticotrophin or cortisol into foetal lambs. J. Endocr. 42, 323-329.

LIGGINS G. C., FAIRCLOUGH R. J., GRIEVES S. A., KENDALL J. Z., 1973. The mechanism of initiation of parturition in the ewe. Rec. Progr. Horm. Res., 29, 111-159.

MARTAL J., LACROIX M. C., 1978. Production of chorionic somatomammotropin (OCS), fetal growth and growth of the placenta and the corpus luteum in ewes treated with 2-bromo- $\alpha$-ergocryptine. Endocrinology, 103, 193-199.

MUSTO N., HAFIEZ A. A., BARTKE A., 1972. Prolactin increases $17 \beta$-hydroxystęroid dehydrogenase activity in the testis. Endocrinology, 91, 1106-1108.

PALMER E., JOUSSET B., 1975. Urinary oestrogen and plasma progesterone levels in non pregnant mares. J. Reprod. Fert. Suppl., 23, 213-221.

PALMER E., TERQUI M., 1977. The measurement of total plasma oestrogens during the follicular phase of the mare's oestrous cycle. Theriogenology, 7, 331-338.

TERQUI M., 1978. Contribution à l'éfude des œstrogènes chez la brebis ef la truie. Thèse Doct. ès Sci. nat., Univ. Paris VI.

THORBURN G. C., NICOL D. H., BASSETT J. M., SHUTT D. A., COX R. I., 1972. Parturition in the goat and sheep; changes in corticosteroids, progesterone, oestrogens and prostaglandin F. J. Reprod. Fert., Suppl., 16, 61-84.

THOMPSON F. N., WAGNER W. C., 1974. Plasma progesterone and oestrogens in sheep during iate pregnancy ; contribution of the maternal adrenal and ovary. J. Reprod. Fert., 41, 57-66.

YENIKOYE, 1977. Efude quantitative de différences génétiques dans le faux de sécrétion de progestérone au cours du cycle æestral chez la génisse. Thèse $3^{\mathrm{e}}$ cycle, Univ. Paris VI, 48 pp. 